\title{
AN ANALYSIS OF ENVIRONMENTAL IMPACTS OF VARIOUS ENVIRONMENTAL ASPECTS FOR INDIAN MANUFACTURING INDUSTRIES
}

\author{
M.S. Narwal ${ }^{1}$, Ajit ${ }^{2}$, Ram Bhool ${ }^{3}$ \\ ${ }^{I}$ Associate Professor, Dept. of ME, Deenbandhu Chhotu Ram University of Science and Technology, Sonipat, Haryana, \\ India \\ ${ }^{2}$ Assistant Professor, Dept. of ME, Rayat Bahra International Institute of Technology \& Management, Haryana, India \\ ${ }^{3}$ Assistant Professor, Dept. of ME, Panipat Institute of Engineering \& Technology, Samalkha, Panipat, Haryana, India,
}

\begin{abstract}
This research paper is focused on the study of various environmental aspects and their impacts arising from the Indian manufacturing industries. Our environment is being polluted day by day due to rapid industrialization. Today the delicate ecosystem of our planet is facing a danger of destruction on a scale as never before in the history of mankind. Forests are diminishing at an alarming rate, landmasses are getting eroded, climate in different parts of the world is undergoing a change due to global warming and clean air and water are increasingly becoming rare commodities. So it is high time to be aware and alert about environmental protection which cannot be done without understanding the environmental aspects. Present study tried to explain the significant environmental aspects arising from Indian manufacturing industries by analyzing the data collected through questionnaire survey. It is observed from collected data that emission to air is most significant environmental aspect in Indian manufacturing industries in respect to severity i.e. the effect of this environmental aspect is more harmful for human beings. Noise environmental aspect is having more efficiency, probability and duration, it means this environmental aspect is produced in each and every manufacturing company and affects the environment. Emission to water is second most important environmental aspect with respect to severity, probability and frequency. The degradation of Land Environmental Aspect effects the environment after the emission to water environmental aspect. But acid deposition, use of hazardous substances and production of toxic waste etc. environmental aspects have moderate significance as they have less probability, less frequency and less duration. So, Manufacturing Industries have to make monitoring plan for all these environmental aspects preferably for emission to air, release to water and noise.
\end{abstract}

Key words: Environmental Aspects, Severity, Duration, Probability and Frequency, Degradation of Land, Hazardous Substances.

\section{INTRODUCTION}

The concept of 'Environmental aspects and their impacts' is an important term in environmental management system. The study of environmental aspect describes the relevant issue(s) related to environment that a management needs to address, irrespective of level of abstraction e.g. waste management, global warming, resource extraction, lack of knowledge about process emissions, toxic material management, and biodiversity. Ideally, a list of environmental aspects defines the identified scope of the responsibility of an environmental management system (EMS). The aspects in company's list are those that the company has identified. So, the priorities given to environmental aspects by the companies differ as they have different method for identification and evaluation of environmental aspects. The environmental aspect concept is well established in companies using an EMS. Environmental aspects occur in each manufacturing activities like emissions to air, releases to water, emission of noise, deforestation, acid deposition, waste management, use of hazardous substances etc. However, they are most commonly connected with manufacturing industries. If the criterion of their occurrence is applied in manufacturing industries one may signify which aspect is more dangerous, which aspect has more probability to occur, which aspect has more frequency and which aspect getting repetitions? Ones the significant environmental aspect and their impact gets identified then manufacturing industries have to make plan for monitoring of these aspect so that their effect can be minimized. The principle impacts of these aspects are air pollution, water pollution, noise pollution degradation of land, damage to wild life, global warming, greenhouse effect, ozone layer depletion, decreased land health and productivity etc. Out of the various aspects arising from manufacturing industries emission to air and releases to water are described as the most significant causing many severe impacts like air pollution, green house 
effect, global warming, ozone layer depletion, water pollution, decreased land health and productivity, degradation of land. Emission of noise aspect producing noise pollution occurs from each and every industry to bigger or smaller extent so this aspect also needs more attention but it is somewhat less harmful for environment as compared to other. These aspects require immediate attention because it is now well established that damage to environmental systems and natural resources has assumed massive proportions and the effects are manifesting themselves in very tangible detrimental forms. So, the companies have to give more concentrations on various environmental aspects for the welfare of lives and there is an urgent need for proper management of the environmental aspects arising from Indian manufacturing industries.

\section{LITERATURE REVIEW}

Literature review is that part of this research paper is to find out the research gap. Literature review takes into consideration the broader concept of sustainable development and outlines how and why companies should be concerned with environmental and social issues in Green Supply Chain Management (GSCM). Common benefits of GSCM in achieving sustainability are enhanced value for cost reduction, customers, and competitive advantage.

\subsection{Global Context}

Welford, (2000), focused on the damage to the environment that is done by industries and organizations and as such attention should be made to these activities in order to reduce their impact on humans and the environment. The issue of global warming is becoming an increasing concern worldwide today as most countries and organizations are now aimed at ensuring that their activities create less environmental impact. Therefore there is a need for industries and organizations to continually review their environmental impacts in order to determine which of the environmental aspect is most significant and needs immediate attention. Ammenberg and Hjelm, (2002), carried out a research on the relationship between environmental management systems and continual environmental performance improvement. From there research, it realised that more than 30000 companies are using standardized environmental management systems according to the ISO14001 or EMAS (eco-management and audit scheme) as a guarantee for good environmental performance. Zackrisson, (2003), determined the environmental aspects when manufacturing products mainly out of metals and polymer in their production phase. The research was aimed to offer justified evidences that a production phase focus in environmental management and to demonstrate a method for identifying and evaluating environmental aspects associated with metals and or polymer in their production phase. Yang and $\mathrm{Li}$, (2004), carried out an environmental management planning for Datong coal Gasification Corporation (DCGC) in the Shanxi province of China in order to check for compliance. They carried out a cleaner production program using the ISO14001 and carried out an environmental management planning collectively with the environmental protection department of Datong Corporation using a monitoring program which helps to determine the extent of compliance with all applicable environmental management and standards. The five small groups of EMCC (Environmental Management Consultative Commission) and other specialist of DCGC identified 66 environmental effects. These environmental effects were evaluated based on physical and business issues. This help in identifying which of the environmental effect is most significant. Ammenberg, (2004), identified three possible methods of evaluating environmental aspects. These methods include the easy evaluation method, comparison in pair's evaluation method and the detailed evaluation method. The three methods of environmental aspects evaluation identified according to Ammenberg gives an accurate result when properly used. The usability of any of the three methods is based on individual understanding. Branco et al., (2005), studied that approximately 1.2 billion people in developing nations lack clean water because most household and industrial wastes are dumped into rivers and lakes without treatment contributing to many waterborne diseases in humans. Nolten et al., (2005), described fundamental elements of ecosystem such as soil, water and biodiversity which are the subject of many agrarian, ecological, biological and hydrological studies. A high percentage of ecosystems consist of arable land which is treated with agrochemical products forms the upper layer of the soil. Large quantities of chemical elements infiltrate the water running off of the cultivated soils thereby entering the animal and human food chain. Franco et al., (2005), they signified that the damage to the environment by the hazardous tannery effluent is becoming an acute problem in the country. The chrome tanning process results in toxic metals, especially chromium III passing to wastewater and are not easily eliminated by ordinary treatment process. Xiamei et al., (2005), they analysed that reduction in the availability of heavy metals in sludge is therefore one of the major concerns associated with land application, particularly in agronomic contexts. Though land application of sludge has been practiced, only relatively small amounts of sludge have been utilized in other industries such as forestry despite its recommendation of its value as a fertilizer. Brorson \& Larsson, (2006), stated that environmental review helps the organization to get a clear view of the environmental state and also helps to identify things that can be improved and which should be part of the company's action plan. Schebek et al., (2006), carried out an assessment for Volkswagen in Emden in Germany to determine its environmental impacts and environmental targets within environmental management system. The main aim of their research was to develop a systematic verifiable and reproducible approach to comply with the revised EMAS scheme. Edday et al., (2006), they analysed that heavy metals emitted either from anthropogenic or natural activities can disperse in environment and may ultimately get deposited in the soil. Plants growing in such 
areas may absorb heavy metals in their body. Although heavy metals like iron, molybdenum, manganese, zinc, copper, magnesium, copper, selenium and nickel have a major role for growth and development of plants, but may be toxic beyond certain level. Principi et al., (2006), according to them environmental contamination with metals through industrial wastes is one of the major health concern of developing countries. Metal pollutants can easily enter the food chain if heavy metals contaminated soils are used for the production of crops. Quazilbash et al., (2006), given importance to waste disposal as the wide spread industrialization in urban areas has drastically reduced land area for waste disposal. Disposal of untreated industrial and domestic wastes into the environment affects both soil and ground water quality. Soil and streams have been used for multifarious purposes including waste disposal. Our careless dumping of wastes has affected these precious resources. Sammalisto, (2007), stated that there is a great difference in the impact on the environment by industries and organization as a result of their operational activities and use of raw materials. Industries and organizations are aimed at transforming resources into finished products in order to benefit their customers and as such affect the environment directly or indirectly. Human activities affect the environment through various ways creating negative impacts to the natural environment and as such need to be reduced considerably to ensure that there is a clean air, water and food for everyone on the planet. Tadasse et al., (2007), they illustrated that the waste water from tanning industries contains highly alkaline and decomposing organic matter, sulphide and organic nitrogen with a high amount of other toxic chemicals, after processing raw hide/skin into finishing leather. Kolomaznik et al., (2008), according to them actuality of ecological problems is emphasized by mankind's growing concern for the damage caused to the environment. The main aspect of this concern is linked with the preservation of living being on our planet. Nouri et al., (2009), according to them release of pollutants differs from industry to industry. The waste from the pulp industry mainly contain carbohydrates, textile industry contain dyes , plating industry contain nickel and leather tanning wastes contain mainly chromium, zinc, copper, sulphides, carbonates, sodium and many other toxic organic compounds and inorganic compounds. Tung et al., (2009), they analysed that most of the hazards coming to human and ecosystem are mostly due to ground water pollution. The untreated sewage, industrial effluents and agriculture wastes are often discharged into the water bodies. Xi et al., (2009), according to them pollution of water and soils by heavy metals is an emerging problem in urban industrialized countries. Since the advent of development through mining, smelting, metallurgy, sewage, warfare and tanning much effect the survival of plants and animals. Okeyode and Moshood, (2010), they signified that soil pollution by metals is essentially different from air or water pollution because the persistence of heavy metals in soil is reportedly much longer than in other compartments of the biosphere. Removal of heavy metals from polluted soil is difficult. Once deposited on the soil certain metals such lead and chromium may be virtually permanent. Xie et al., (2011), analysed that Industrial dyeing processes in textile industries generate a huge amount of wastewater, because the production lines have to be washed out each time when the dye changes. This also shows that dying process of textile industry produce large amount of waste water and thus causes many impacts. Samia Sajid et al., (2013), they developed a better understanding of the textile processes, related environmental issues and the available techniques for controlling the environmental pollution and also to understand the components of ISO 14001 Environmental Management System (EMS).

\subsection{Indian Context}

Agarwal, H.O., (1999), reported that the tremendous advancement of industrialization resulted into economic development had also continuously degraded the human environment. Further, urbanization, over-population and poverty also intensified the problem. Kumar, V, (2000), observed that there is an acceptance of the ideas regarding the survival of animal and plant life coming from people. The hoary tradition of our country in conservation continues even today and we have the inspiring example of the bishnoi community in Rajasthan, Haryana and Uttar Pradesh, dedicated to protecting our trees and wild animals. Saxena and Srivastava, (2002), suggested that the effluent is an inevitable consequence of industrial process. In arid and semi arid regions of the country, where shortage of water becomes limiting factor, the effluent is being used for irrigational purposes by the farmers in agriculture and agro-forestry practices. Viti et al., (2003), they signified that the contamination of the environment with heavy metals is a serious problem because of industrial activities and sewage sludge applications have largely contributed to the wide spread of these elements in the terrestrial environment. Meena et al., (2004), they analysed that compared with other kinds of water, groundwater is normally preferred because it tends to be less contaminated directly by wastes and organisms. However in the wake of recent industrialization and fast urbanization the quality of groundwater has become an increasing concern due to contamination by various toxic chemicals. Upreti et al., (2004), they studied the Effect of toxic chemicals on plants and animal kingdom. The phototoxic impact of the heavy metal was observed on crop such as cabbage, water chestnut, tomatoes, chilies and rice. Amita et al., (2005), they studied that chemicals such as zinc chloride, mercuric chloride and formaldehyde are used as disinfectants, sodium chloride in curing and as bleaching powder and sodium fluoride to prevent putrefaction, lime in liming, sodium sulphate, ammonium chloride, borax and hydrochloric acid in deliming, sodium for decreasing and basic or acidic dyes in leather finishing Chunillal et al., (2005), they analysed that impact of toxicity was evident as visible symptoms of chlorosis, yellowing and immature fall of leaves, poor growth and retarded flower, fruit and green yields. Metabolic 
alterations by metal exposure have also been described in plants either by direct effect on enzymes or other metabolites. This was possibly attributed to the imbalance of nutrients and nutritional disorders in the plants due to metal interactions with plant nutrients. Waziri, (2006), they determined that different types of heavy metals carried from waste water effluent are liberally let out into the nearby rivers causing contamination in them. Drinking water may be contaminated by various toxic metals. The impact of the effluents is so stupendous that the water has become unfit for drinking and irrigation. Kumar and Mani, (2007), determined that the tannery waste is always characterized by its strong colour (reddish dull brown), high BOD (biochemical oxygen demand), high $\mathrm{pH}$, and high dissolved solids. The other major chemical constituents of the waste from the tanning industry are sulphide and chromium. These chemicals mixed with water are discharged from the tanneries and pollute the ground water permanently and make it unfit for drinking, irrigation and general consumption. Malarkodi et al., (2007), stated that problem of pollution by metals have aggravated and affected the ecological balance and caused serious health hazards because of the release on land as well as dumping on the surface water. Metallic components reach to ground water and lead to contamination due to accumulation and resulted in a series of well documented problems in living things. Tiwari et al., (2008), they studied that pollution of the biosphere with toxic metals has accelerated dramatically since the beginning of the industrial revolution. Increasing industrialization and population develops the standard of living, which results in highly contaminated atmosphere due to the drainage and wastage from these industries. Karthikeyan et al., (2010), they studied that industrial effluents consist of organic compounds along with inorganic complexes and other non biodegradable substances. These pollutants not only alter the quality of ground water and soil but also pose serious problems. Azumi and Bichi, (2010), illustrated that the rapid industrialization plays an important role in polluting the environment and causes severe degradation in pedosphere, hydrosphere and atmosphere. Water used in industries creates a waste that has potential hazard for our environment because of the introduction of various contaminants such as heavy metals into soil and water resources. Tiwari Jeetendra Kumar and Rawani A. M., (2012), they studied the environmental impact due to cement production process in ACC cement plant of Chhattisgarh state, India. The study shows that how one can generate aspects from activities and can analyze that which aspects are significant or insignificant. The case study suggests that the aspects like fugitive dust emission and noise need to be emphasized and require more attention and to be managed. Veena Bamba et al., (2012), they focused on environmental awareness in present scenario due to unawareness among people towards nature because in present technical era environment is being depleted day by day, forests are diminishing at an alarming rate, landmasses are getting eroded, climate in different parts of the world is undergoing a change due to global warming and clean air and water are increasingly becoming rare commodities. So they focused awareness and alertness about environmental protection.

Chandran M. Vijaya et al., (2013), introduced that Environmental Impact Assessment and Environmental Management Plan are widely used as tools of Environmental appraisal in project analysis and plays an effective role in supporting the sustainable development. Poor quality of data or information was the major bottleneck in improving and strengthening the EIA reports. The factors that determine the quality of EIA reports are legislations, quality of consultant groups and their expertise, scoping, extent of land use change coverage of EIA reports, public response and nature of projects.

\subsection{Various Environmental Aspects}

These are various drivers for green supply chain Practice (GSCP) which are observed from the literature review and also important for Global and Indian manufacturing environment. The list of overall list of drivers are given below

Table 1 Various Environmental Aspects and their Impacts.

\begin{tabular}{|c|c|}
\hline Aspects & Potential Impacts \\
\hline $\begin{array}{l}\text { Discharges to stream OR } \\
\text { Emissions to water }\end{array}$ & $\begin{array}{l}\text { Water quality impacts } \\
\text { Biodiversity impacts } \\
\text { Land health and } \\
\text { productivity }\end{array}$ \\
\hline Emissions to air & $\begin{array}{l}\text { Air pollution, Local air } \\
\text { quality decreases } \\
\text { Climate change } \\
\text { Ozone depletion } \\
\text { Green house effect }\end{array}$ \\
\hline Waste management & $\begin{array}{l}\text { Acid deposition } \\
\text { Water quality impacts } \\
\text { Local air quality } \\
\text { decreases } \\
\text { Degradation of landfills }\end{array}$ \\
\hline $\begin{array}{l}\text { Use of hazardous } \\
\text { substances }\end{array}$ & $\begin{array}{l}\text { Local air quality impacts } \\
\text { Acid deposition }\end{array}$ \\
\hline Production of toxic waste & $\begin{array}{l}\text { Air pollution } \\
\text { Land health and } \\
\text { productivity } \\
\text { Acid deposition } \\
\text { Water quality impacts }\end{array}$ \\
\hline Noise & $\begin{array}{l}\text { Noise pollution } \\
\text { Hearing disability } \\
\text { impacts }\end{array}$ \\
\hline Deforestation & $\begin{array}{l}\text { Damage to wild life } \\
\text { Degradation of land }\end{array}$ \\
\hline Chemical spills and leaks & $\begin{array}{l}\text { Land health and } \\
\text { productivity } \\
\text { Depletion of non- }\end{array}$ \\
\hline
\end{tabular}




\begin{tabular}{|c|c|}
\hline & $\begin{array}{l}\text { renewable resources } \\
\text { Water quality impacts } \\
\text { Biodiversity impacts }\end{array}$ \\
\hline $\begin{array}{l}\text { Land Mining, construction } \\
\text { and drainage }\end{array}$ & $\begin{array}{l}\text { Disturbance and soil } \\
\text { erosion, loss of soil } \\
\text { cover, water logging, } \\
\text { disturbs groundwater, } \\
\text { loss of habitats }\end{array}$ \\
\hline $\begin{array}{l}\text { Emissions of volatile } \\
\text { organic } \\
\text { Compounds }\end{array}$ & $\begin{array}{l}\text { Land health and } \\
\text { productivity } \\
\text { Greenhouse } \\
\text { emissions } \\
\text { Air quality } \\
\text { Biodiversity impacts } \\
\text { Water quality impacts }\end{array}$ \\
\hline Service delivery & $\begin{array}{l}\text { Greenhouse gas } \\
\text { emissions } \\
\text { Air quality impacts } \\
\text { Water quality impacts } \\
\text { Biodiversity impacts } \\
\text { Land health and } \\
\text { productivity. }\end{array}$ \\
\hline $\begin{array}{l}\text { Over consumption of } \\
\text { natural resources }\end{array}$ & $\begin{array}{l}\text { Depletion of minerals, } \\
\text { raw materials, and } \\
\text { energy sources }\end{array}$ \\
\hline $\begin{array}{l}\text { Discharges to stream OR } \\
\text { Emissions to water }\end{array}$ & $\begin{array}{l}\text { Water quality impacts } \\
\text { Biodiversity impacts } \\
\text { Land health and } \\
\text { productivity }\end{array}$ \\
\hline Emissions to air & $\begin{array}{l}\text { Air pollution, Local air } \\
\text { quality decreases } \\
\text { Climate change } \\
\text { Ozone depletion } \\
\text { Green house effect }\end{array}$ \\
\hline
\end{tabular}

\subsubsection{Direct Environmental Aspect}

These are the aspects over which a company can be expected to have an influence and control. For example, emissions from processes OR direct aspects are connected with those activities of the enterprise which are managed and controlled by this particular enterprise. While defining the direct aspects one can order them according the places they occur in the enterprise, i.e. assembly room, dispatch, storehouses and packing area.

\subsubsection{Indirect Environmental Aspect}

Indirect environmental aspects are those which can occur in combination with actions, products or services which are not fully controlled and supervised by the enterprise. During the identification of the indirect aspects one can use an interview with contractors, subcontractors and customers and the analysis of the use of materials, the activities of subcontractors and co-operating companies in the supply chain. Examples of indirect aspects are leftovers of packaging, most commonly included into the category of municipal waste by the recipient of the final products. Indirect aspects arise in the surrounding of the enterprise and not directly in the enterprise.

\section{RESEARCH METHODOLOGY}

Research methodology is based on empirical data collected through a questionnaire survey. A questionnaire was used to collect the primary data secondary data. It combined both closed and open-ended questions. Informal discussion was also held with environmental officers and people/organizations responsible to the environment and standardization in India. For the acquisition of primary data a questionnaire was administered to the manufacturing industries in the study area. The survey methodology is used for study. The main objective of the survey is to identify significant environmental aspects arising from Indian manufacturing industries. Data is collected through questionnaire survey. The questionnaire was administered in 60 industries in the northern and southern region of India through emails, telephone calls and also by making direct contact to the company. The outcomes from twenty industries have been received and analysed by ammenberg detailed evaluation method for significant environmental aspects assessment.

\subsection{Industry Database}

Primary data is the main source of information for the study. However, some secondary sources of data would be employed. The secondary sources of data would include books, published electronic and print journals and information from important people on environment in India. The data base of 60 manufacturing industries located in different parts of India has been extracted from industrial directories for questionnaire survey. This has the name of company, product manufactured, location and postal address. The average numbers of employees in most industries are more than hundred. In India major industries are automotive parts manufacturing industries supplying products to O.E.M. (original equipment manufacturing) industries. Automotive, fabrication and sheet metal industries were selected for the present study. The reasons for selecting these manufacturing industries are as under

- Most of the pollution activities occur from the manufacturing industries.

- The manufacturing industries are the back bone of any economy of nation.

\subsection{Development of Questionnaire}

Based on the study of literatures a questionnaire is designed which has two sections and it contain 28 questions in all. Many of them are of tick mark type. Section-A contain five questions regarding general information about company like name, address, product name, number of employees working, 
type of working and information regarding method of furnacing (if any).Section-B have eleven questions relative to the direct or indirect environmental impacts and aspects. Six questions are of environmental aspects emphasis type.

There is also one question which signifies the level of importance given to the environmental performance by top management. Questionnaire also have question regarding Environmental Management System (EMS) and ISO 14001certification. Whether company situated in rural or urban area? Will it works under (EMAS) certified Environmental Management System or not? These entire questions designed to collect the maximum information from the industries regarding environmental aspects.

The data is collected through personnel contacts, email, telephonically and by post from Indian manufacturing industries. Table 2 describes various questions asked in questionnaire survey for environmental aspects and impacts analysis.

Table 2 Questions on Various Environmental Aspects

\begin{tabular}{|c|c|}
\hline Sr.No. & Questions asked in Questionnaire \\
\hline $\begin{array}{l}\text { Section-A } \\
\text { (General } \\
\text { information) }\end{array}$ & $\begin{array}{l}\text { 1. Organisation and products name } \\
\text { 2. Number of employees } \\
\text { 3. Annual turnover of company } \\
\text { 4. Fuel for furnace heating } \\
\text { 5. Working type for employees }\end{array}$ \\
\hline $\begin{array}{l}\text { Section-B } \\
\text { (Environmental } \\
\text { information) }\end{array}$ & $\begin{array}{l}\text { Regarding EMS certification } \\
\text { Related to negative environmental } \\
\text { impacts fo } \\
\text { Regarding plan for monitoring the } \\
\text { impacts } \\
\text { On positive environmental aspect by } \\
\text { industry(if any) } \\
\text { About the location of company } \\
\text { Related to Emphasis given by the } \\
\text { company } \\
\text { Importance given by top management to } \\
\text { environmental performance } \\
\text { About ISO14001 or EMAS certification }\end{array}$ \\
\hline
\end{tabular}

\subsection{Profile of Respondents}

Telephone interviews were first conducted to inform and ascertain the interest of the company in the study. Sixty (60) companies were selected for the administration of the questionnaire. The structured questionnaires were administered personally to some of the directors of the departments responsible to the environment in the company. Some questionnaires were left with the personnel manager (PM) or human resource manager (HRM) of those industries whom the questionnaire could not be administered to personally. Results from 20 industries are used for the study showing a response rate of $33 \%$. The environmental manager was chosen since she/he is in charge of the environment and is knowledgeable about the EMS process. Where the company did not have such a position, the questionnaire was administered to the general manager, the Chief Executive Officer or the production manager. The questionnaire was administered only to the manufacturing industries.

\section{ANALYSIS AND OBSERVATION OF DATA}

The collected data which was obtained by questionnaire survey is analysed by Detailed Evaluation Method as given by ammenberg (2004). This method is based on weighting criterion against environmental aspects to determine that which of the environmental aspect is most significant for Indian manufacturing industries. In this method weights between 0 and 5 are assigned to each environmental aspect with respect to their relevance to each of the criteria that the environmental aspect is been weighed against. Environmental aspect that is of great relevance to the criteria is given the weight 5. Medium relevance is given the weight 3, small relevance is given the weight 1 and no relevance is given the weight 0 . The weights obtained are summed up and multiplied by the quantity of the environmental aspect to determine which of the environmental aspect is most significant.

These quantities of the environmental aspect represented with $\mathrm{K}$ and referred to as environmental load by Zackrisson (2003). The sum is used to determine the significance of each environmental aspect. This is achieved by adding all the points obtained from A to D (as four criterion are used) and then multiply by $\mathrm{K}$. This can be expressed using and equation $(\mathrm{A}+\mathrm{B}+\mathrm{C}+\mathrm{D}) * \mathrm{~K}$ (Ammenberg, 2004). Quantities of total environmental aspect represented by $\mathrm{K}$ which is 10 ,

\subsection{Observation of Collected Data}

The most used criteria in the process of the environmental impact assessment are severity, probability, frequency and duration which are defined as

\section{(a) Severity}

It is related to the level of the exposition of the environment to the aspects/ impact, including air, water, soil, natural resources, flora, fauna, humans, etc.

\section{Scale of severity}

(5-very dangerous, must be repaired, 4- serious, hard to repair, 3-moderate, could be repaired, 2-minor effects that are easily remedied 1-harmless, negligible impact)

(b) Probability

It is used as the indicator of the possibility of something to happen.

\section{Scale of probability}

(5- almost certain, 4-likely, 3-possible, 2-rare, 1-almost incredible) 
(c) Frequency

It describes how often some aspects/impacts could occur in the environment of an organization.

\section{Scale of frequency}

(5-continuous - more than 3 times per week, 4 -very often, 1-2 times per week, 3-regular - it happens once a month, 2 intermittent -3 to 4 times per year, 1-rare less than one time a year)

\section{(d) Duration}

It describes the number of times some aspect/impact occurred during the investigation. Quantities of total environmental aspect represented by $\mathrm{K}$ which is 10 ,

Table 3 Significance Assessment of Ten Different Aspects Using Four Criteria

\begin{tabular}{|l|l|l|l|l|l|}
\hline $\begin{array}{l}\text { Aspects } \\
\text { /Impacts }\end{array}$ & $\begin{array}{l}\text { Sever } \\
\text { ity( } \\
\text { A) }\end{array}$ & $\begin{array}{l}\text { Probabili } \\
\text { ty(B) }\end{array}$ & $\begin{array}{l}\text { Frequenc } \\
\mathrm{y}(\mathrm{C})\end{array}$ & $\begin{array}{l}\text { Duratio } \\
\mathrm{n}(\mathrm{D})\end{array}$ & $\begin{array}{l}\text { Total } \\
\text { Sum }\end{array}$ \\
\hline $\begin{array}{l}\text { Water } \\
\text { pollution }\end{array}$ & 4 & 4 & 4 & 3 & 150 \\
\hline $\begin{array}{l}\text { Damage } \\
\text { to wild } \\
\text { life }\end{array}$ & 3 & 2 & 2 & 2 & 90 \\
\hline $\begin{array}{l}\text { Local air } \\
\text { quality }\end{array}$ & 5 & 4 & 4 & 4 & 170 \\
\hline $\begin{array}{l}\text { Climate } \\
\text { change }\end{array}$ & 4 & 3 & 3 & 4 & 140 \\
\hline $\begin{array}{l}\text { Acid } \\
\text { depositio } \\
\text { n }\end{array}$ & 5 & 2 & 1 & 1 & 90 \\
\hline $\begin{array}{l}\text { Ozone } \\
\text { depletion }\end{array}$ & 4 & 2 & 2 & 4 & 120 \\
\hline $\begin{array}{l}\text { Use of } \\
\text { hazardou } \\
\text { s subs. }\end{array}$ & 3 & 2 & 1 & 1 & 70 \\
\hline $\begin{array}{l}\text { Producti } \\
\text { on of } \\
\text { toxic } \\
\text { waste }\end{array}$ & 4 & 3 & 2 & 1 & 100 \\
\hline $\begin{array}{l}\text { Noise } \\
\text { pollution }\end{array}$ & 2 & 4 & 5 & 5 & 160 \\
\hline $\begin{array}{l}\text { Degradat } \\
\text { ion of } \\
\text { land }\end{array}$ & 3 & 2 & 2 & 3 & 100 \\
\hline
\end{tabular}

In the above table 3 water pollution impact arise due to emission of waste water, damage to wild life arise due to deforestation, local air quality affected by emission to air and emission of waste water. Climate change arises due to emission to air and deforestation, acid deposition is the result of improper waste management and emission of wastage to water. Ozone depletion, green house effect and global warming is also the result of emission to air, use of hazardous substances and production of toxic waste causes water pollution and air pollution respectively. Noise pollution is the result of emission of noise from various industries near by the populated areas. Degradation of land arises due to emission of waste water and deforestation. These are the environmental aspects and impacts which arise from Indian manufacturing industries. Above table represents the impacts of related environmental aspects which are (emission to water, deforestation, emission to air, improper waste management, use of hazardous substances, production of toxic waste and emission of noise ) observed from the literature review and also having the more importance for Indian manufacturing industries. From the table following observations can be made.

(i) Emission to air environmental aspect affects the local air quality so it produces air pollution which is the cause for impacts like global warming, green house effect and ozone layer depletion. This aspect is having more severity, more probability and more frequency. It means this aspect is very dangerous, having more possibility to occur and having more repetition. The sum of this environmental aspect is 170 .

(ii) Emission of noise environmental aspect has the noise pollution environmental impact which is more significant because this aspect is having the more probability, more frequency and more duration as compared to other environmental aspects. The sum of this environmental aspect is 160 .

(iii) Releases to water environmental aspect produce the water pollution which is having the more severity, probability, and frequency. The water released to ground also produces impacts like damage to wild life, decreased land health and productivity and effect local air quality. This aspect is also more harmful for environment. The sum of this environmental aspect is 150.

(iv) The impacts like damage to wild life and degradation of land arising from deforestation and emission to water respectively have moderate significance as their frequency, duration and probability is less as compared to other. The sum of these impacts is 100 .

(v) The rest of the aspects like acid deposition, use of hazardous substances and production of toxic waste polluting land, water and air respectively also have moderate significance and company management have to take necessary actions to minimize them.

\section{CONCLUSIONS}

The objective of this paper is to study different environmental impacts of various environmental aspects and to find out significant environmental aspects for Indian manufacturing industries. From the analysis of questionnaire data we came to following conclusions

- The impacts like climate change, ozone layer depletion, green house effect's, global warming results due to air pollution because the air emissions from manufacturing industries contains $\mathrm{CO} 2, \mathrm{NO} 2$ 
and $\mathrm{SO} 2$ gases which are harmful to the environment. so, emission to air is the most significant aspect arising from the industries due to more severity, more probability and more frequency and manufacturing firms have to take much care about it and has to make its monitoring plans.

- Emission of Noise is the most significant environmental aspect as it is more repetitive as compared to other environmental aspects. It produces noise pollution environmental impact from all industries to greater or small extent. So, manufacturing industries have to think about this aspect.

- Water which is released to surrounding having oxygen consuming substances, chlorinated substances and impurities which affects the water quality and decreases land health and productivity. So, the emission to water is second most important environmental aspect with respect to severity, probability and frequency. Manufacturing industries have to think about its monitoring plans.

- Production of toxic waste, use of hazardous substances, deforestation, acid deposition environmental aspects were having more severity but their frequency and probability is less. So these come under moderate categories and manufacturing industries have to make proper waste management plans to reduce their impacts.

\section{REFERENCES}

[1]. Agarwal, H.O., (1999), International law and human rights. Allahabad: Central law publications, p, 562.

[2]. Amita, D.A., Verma, S., Tare, V. and Bose, D. (2005), in oxidation of chromium (III) in tannery sludge for chromium (IV): Field observations and theoretical assessment, Journal of Hazardous matter, vol.121, 215-222.

[3]. Ammenberg, J., \& Hjelm, O. (2002), the connection between environmental management system and continual environmental performance improvements, Cooperate environmental strategy, vol. 9 (2), 112-116.

[4]. Ammenberg, J., (2004), Miljö Management, studentlitteratur, university of Lund, Sweden.

[5]. Azumi DS, Bichi MH. (2010), Industrial pollution and heavy metals profile of Challawa River in Kano, Nigeria. Journal of Applied Science in Environmental Sanitation, vol.5 (1), 23-29.

[6]. Branco R, Chung A P, Verissimo A, Morais P V, (2005), Impact of chromium-contaminated wastewaters on the microbial community of a river. FEMS Microbiology Ecology, vol.54, 35-46.

[7]. Brorson, T., \& Larsson, G. (2006), Environmental Management, how to implement an environmental management system within a company or other organization, EMS AB, Stockholm Sweden,
[8]. Chandran M. Vijaya, Aregai Mekonen, Reddy T. Byragi, (2013), environmental appraisal - Indian scenario, International journal of engineering and management sciences, vol. 4(2), 218-222.

[9]. Chunillal, V., Kindness, A. and Jonnaladda, S.B. (2005), Heavy metal uptake by two edible Ammaranthus herbs grown on soil contaminated with lead, mercury, cadmium and nickel, Journal of Environmental Science and Health, vol.40(9), 375-384.

[10]. Edday., N.O, Odoemelan., S.A, and Mbaba., A, (2006), Elemental composition of soils in some dump sites, Electronically, Journal of Environmental Agriculture and food Chemistry, vol. 5(4), 1399-1465.

[11]. Karthikeyan K, Chandran C, Kulothangan S, (2010), Biodegradation of oil sludge of petroleum waste from automobile service station using selected fungi. Journal of Ecotoxicology and Environmental Monitoring, vol. 20(3), 225-230.

[12]. Kolomaznik K, Adaneck M, Andel I, (2008), Leather waste- Potential threat to human health a new technology of its treatment. Journal of Hazardous Matter, vol.160 (2-3), 514520.

[13]. Kumar, S.S. and Mani, A, (2007), Measurement of Physical and transport properties of tannery effluent (soak liquor), International Communication in Heat and Mass Transfer, vol.3(2),339-346.

[14]. Kumar, V, (2000), Modern methods of teaching environmental education. New Delhi: Sarup \& Sons.

[15]. Malarkodi, M., Krishnasamy, R., Kumaraperumal, R. and Chitdeshwari, T.(2007), Characterisation of heavy metal contaminated soils of Coimbatore district in Tamil Nadu, Journal of Agronomy, vol. 6(1), 147- 151.

[16]. Meena, A.K., Mishra, G.K., Nagpur, P.N. and Rajagopal, C. (2004), Removal of copper from aqueous solution by different adsorbents, JEP, vol.24 (5), 361-370.

[17]. Noltan, M.J.M., Oosthoek, A.J.P., Rozema, J. and Aerts, R. (2005), Heavy metal concentrations in a soil plant snail food chain along a terrestrial soil pollution gradient, Environmental Pollution, vol.138(1), 178- 190.

[18]. Nouri J, Khorasani N, Lorestani B, (2009), Accumulation of heavy metals in soil and uptake by plant species with phytoremediation potential. Environmental Earth Science, vol.59, 315-323.

[19]. Okeyode I.C and Moshood I.A (2010), Elemental Compositions of The Soil of Ogun- Osun River Basins Development Authority Headquaters, Ogun-state, Nigeria Indian Journal of Science and Technology, vol. 3(3), 335-337. [20]. Principi, P.; Villa, F.; Bernasconi, M. \& Zanardini, E., (2006), Metal toxicity in municipal wastewater activated sludge investigated by multivariate analysis and in situ hybridization. Water Research, vol.40, 99-106.

[21]. Quazilbash AA, Farayal R, Naqui KB, (2006), Efficacy of indigenous Bacillus species in the removal of chromium from industrial effluent. Biotechnology, vol.5 (1), 12-20.

[22]. Samia Sajid, Shafaqat Ali, Fozia Dogar, Muhammad Bilal Shakoor, Khadija Siddique, Lubna Taj, (2013), 
Implementation Study of ISO 14001- EMS Standards in Processing Unit of Nimra Textiles, Greener Journal of Environmental Management and Public Safety, vol.2 (3),121136.

[23]. Sammalisto, K. (2007), Environmental management systems-a way forward towards sustainable development in Universities, University of Lund, IIIEE, Sweden.

[24]. Santos J. Franco and Anna Huttenlocher, (2005), Regulating cell migration: cell pains make the cut, Journal of Cell Science vol.118 (17), 3829-3838.

[25]. Saxena, S. and Shrivastava, P. (2002), Ground water quality of a typical urban settlement, A case study of impact of town planning, Pollution Research, vol.21, 223- 226.

[26]. Schebek, L., Buchgeister, J., \& Gernuks, M., (2006), Assessment of environmental aspects and determination of environmental targets within environmental management systems (EMS) - development of a procedure for Volkswagen. Journal on cleaner production, vol.15, 10631075.

[27]. Tadesse, I., Isoaho, S.A., Green, F.B. and Puhakka, J.A. (2007), Lime enhanced chromium removal in advanced integrated wastewater pond system bioresource technology, Elsevier, vol. 97(4), 529-534.

[28]. Tiwari Jeetendra Kumar and Rawani A. M. (2012), Environmental impact analysis: Case studies of ACC cement plant, Journal of Environmental Research and Development, vol.7 (2), 130-136.

[29]. Tiwari KK, Dwivedi S, Mishra S, (2008), Phytoremediation efficiency of Portulaca tuberose sox and Portulaca oleracea L. Naturally growing in an industrial effluent irrigated area in Vadodara, Gujarat. India. Environmental Monitoring and Assessment, vol.147, 15-22.

[30]. Tung, Y.T., J.H. Wu, C.Y. Huang, Y.H. Ku and S.T. Chang, 2009. Antioxidant activities and phytochemical characteristics of extracts from Acacia confusa bark. Bioresour. Technol., vol.100, 509-514.

[31]. Upreti, R.K., Srivastava, R and Chaturavedi, U.C. (2004), Gut microflora and toxic metals Chromium as a model, Indian Journal of Medical Research, vol.119, 49-59.

[32]. Veena bamba, Anjali, (2012), Environment awareness in present scenario, International Journal of Research in Economics \& Social Sciences, vol. 2(5).

[33]. Viti, C., Pace, A. and Giovannetti, L., (2003), Characterization of chromium resistant bacteria isolated from chromium- contaminated soil by tannery activity, Current Microbiology, vol.46(7)1-5.

[34]. Waziri, M. (2006), Physicochemical and Bacteriological investigation of surface and ground water of Kumadugu- Yobe Basin, PhD thesis, University of Maiduguri, Nigeria, 88-96.

[35]. Welford, R. (2000), corporate environmental management 3, toward sustainable development, Earth scan Publications Lt, London, UK.

[36]. Xi, X.Z., Xin, T.J., Duan, L.X. and Pei, J. (2009), Isolation, identification and characterization of cadmium resistant Pseudomonas aeruginosa strain, Journal of Central South University Technology, vol.16(6), 0416-0421.
[37]. Xiamei, L., Qitang, W., Banks, M.K. and Ebbs, D.S. (2005), Phytoextraction of zinc and copper from sewage sludge and impact on agronomic characteristics, Journal of environmental science and health, vol.40(4), 823-838.

[38]. Xie, K., Cheng, F., Zhao, W., Xu, L., (2011), Micelle dyeing with low liquor ratio for reactive dyes using dialkyl maleic acid ester surfactants, journal of Cleaner Production, vol.19(4), 332-336.

[39]. Yang, Z. F., \& Li, W. (2004). Environmental management planning for Datong Coal Gasification Corporation, Shanxi province Environmental informatics achievers, vol.2 (3) 197-211

[40]. Zackrisson, M. (2003). Environmental aspects when manufacturing products mainly out of metals and/or polymer Journal of cleaner production vol.13, 43-49

\section{BIOGRAPHIES}

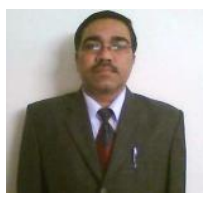

M.S. Narwal is working as an Associate Professor in the Department of Mechanical Engineering at D.C.R. University of Science \& Technology Murthal, Sonepat (Haryana). $\mathrm{He}$ has received his B.Tech degree in Mechanical Engineering from Kurukshetra (Now NIT Kurukshetra). He has received his Ph.D degree from M.D.U Rohtak (India). He is life member of ISTE, Institution of Engineers and Indian Institution of Industrial Engineering. He has published more than 20 research papers in journals \& conferences at national and international level. He has more than 17 years teaching experience in Mech Engineering

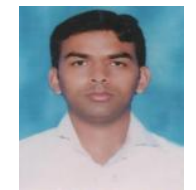

Ajit received his B. Tech. degree in Mechanical Engineering from Chotu Ram State College of Engineering in 2002, and M. Tech. degree in Mechanical Engg. From Deenbandhu Chhotu Ram University of Science and Technology, Sonipat, (Haryana) in 2013. Ajit is an Assistant Professor, with Department of Mechanical Engg. in Rayat Bahra International Institute of Technology and Management

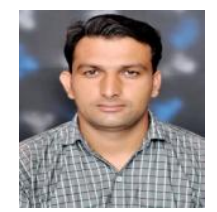

Ram Bhool received his B. Tech. degree in Mechanical Engineering from Shree Ram Mulkh Institute of Engineering and Technology, Naraingarh (Ambala) under Kurukshetra University, in 2011, and M. Tech. degree in Mechanical Engg. From Deenbandhu Chhotu Ram University of Science and Technology, Sonipat, (Haryana) in 2013. Ram Bhool is an Assistant Professor, with Department of Mechanical Engg. in Panipat Institute of Engineering and Technology, Samalkha Near Panipat (Haryana). 